\title{
PRELIMINARY NOTE ON THE SIZE AND CONDI- TION OF THE CENTRAL NERVOUS SYSTEM IN ALBINO RATS EXPERIMENTALLY STUNTED.
}

BY

SHINKISHI HATAI, Ph.D.

(Associate, The Wistar Institute of Anatomy and Biology.)

For these observations five litters of rats were so divided into two groups that the average body weight was nearly the same in both and one group was given the full laboratory ration, while to the other was fed the minimal amount of bread, corns and cereals.

The normally fed group constitutes the "first controls," and the underfed rats, the "stunted group." For further comparison, young rats with the approximately same body weight as the "stunted group," but much younger, were taken for the "second controls."

Beginning at the age of thirty days, the underfeeding considerably retarded the growth of the stunted group so that when they were, on the average, I70 days old they weighed 91.5 grams, whereas the "first controls" - of the same average age-weighed 146.5 grams. The younger rats from 80 to 100 days old which formed the "second controls," weighed on the average 86.3 grams. It must be remembered that during the time the behavior experiments were carried on (for nearly thirty days), the experimented rats were fed with normal diet and as a consequence these rats gained somewhat rapidly in body weight. Therefore the possibility of obtaining permanently stunted rats by means of underfeeding is still undetermined. All the rats were killed and weighed immediately after the behavior experiments were ended.

The main results obtained from the present experiments are exhibited in the following table.

External characters. - The most conspicuous external differences between normal and stunted rats as shown by the stunted rats are in the length of the body and of the tail, both of which 


\section{Fournal of Comparative Neurology and Psychology.}

were considerably reduced with respect to the body weight. ${ }^{1}$ This peculiar difference, as is seen from the table, holds true in every case. Further, the ratio between the length of the body and

TABLE I.

\begin{tabular}{|c|c|c|c|c|c|c|c|c|c|c|c|}
\hline$\underset{\dot{\Phi}}{\dot{W}}$ & 悤 & 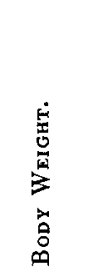 & 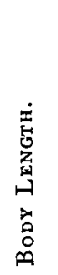 & 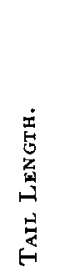 & 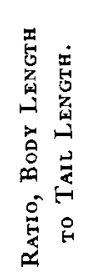 & 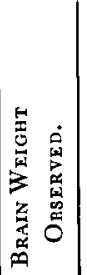 & 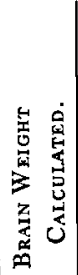 & 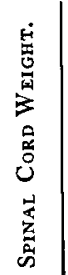 & 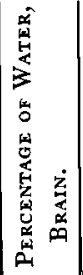 & 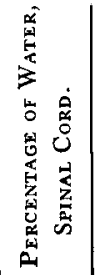 & 量 \\
\hline $\begin{array}{l}\text { F. } \\
\text { F. } \\
\text { F. }\end{array}$ & \begin{tabular}{|c|} 
days. \\
215 \\
215 \\
$80-100$
\end{tabular} & $\begin{array}{l}\text { grams. } \\
186.2 \\
106.2 \\
105.7\end{array}$ & $\begin{array}{r}m m . \\
\mathbf{1} 89 \\
\mathbf{1} 55 \\
\text { I } 55\end{array}$ & $\begin{array}{r}m m . \\
158 \\
112 \\
131\end{array}$ & & $\begin{array}{l}1.8996 \\
1.6325 \\
1.6313\end{array}$ & & $\begin{array}{l}.5597 \\
.4030 \\
.4049\end{array}$ & $\begin{array}{l}78.365 \\
78.623 \\
78.900\end{array}$ & $\begin{array}{l}70.573 \\
72.64 I \\
72.925\end{array}$ & $\begin{array}{l}\text { Ist control } \\
\text { stunted } \\
\text { 2d control }\end{array}$ \\
\hline $\begin{array}{l}M \ldots . . \\
M \ldots . . \\
M \ldots\end{array}$ & $\mid \begin{array}{c}182 \\
182 \\
80-100\end{array}$ & $\begin{array}{r}186.7 \\
113.7 \\
99.7\end{array}$ & $\begin{array}{l}190 \\
155 \\
157\end{array}$ & $\begin{array}{l}\text { I } 54 \\
109 \\
121\end{array}$ & & \begin{tabular}{|}
1.6578 \\
1.5678 \\
1.7029
\end{tabular} & & \begin{tabular}{|l|}
.4862 \\
.3756 \\
.4059
\end{tabular} & $\begin{array}{l}78.447 \\
78.772 \\
78.971\end{array}$ & $\begin{array}{l}70 \cdot 547 \\
73 \cdot 003 \\
73 \cdot 12 \mathrm{I}\end{array}$ & $\begin{array}{l}\text { Ist control } \\
\text { stunted } \\
2 \mathrm{~d} \text { control }\end{array}$ \\
\hline $\begin{array}{l}\mathbf{M} \ldots \ldots \\
\mathbf{M} \ldots \ldots \\
\mathbf{M} \ldots \ldots\end{array}$ & $\begin{array}{c}164 \\
164 \\
80-100\end{array}$ & $\begin{array}{r}119.1 \\
77.6 \\
87.4\end{array}$ & $\begin{array}{l}167 \\
137 \\
154\end{array}$ & $\begin{array}{l}130 \\
100 \\
119\end{array}$ & & $\begin{array}{l}1.667 x \\
1.5884 \\
1.7156\end{array}$ & & $\begin{array}{r}.4524 \\
.3573 \\
3579\end{array}$ & $\mid \begin{array}{l}78.315 \\
78.374 \\
78.870\end{array}$ & $\begin{array}{l}71.353 \\
71.760 \\
72.981\end{array}$ & $\begin{array}{l}\text { Ist control } \\
\text { stunted } \\
2 \mathrm{~d} \text { control }\end{array}$ \\
\hline $\begin{array}{l}\mathrm{F} \ldots \ldots . \\
\mathrm{F} \ldots \ldots \\
\mathrm{F} \ldots \ldots\end{array}$ & $\mid \begin{array}{c}164 \\
164 \\
80-100\end{array}$ & $\begin{array}{r}126.9 \\
89.3 \\
61.7\end{array}$ & $\begin{array}{l}170 \\
140 \\
128\end{array}$ & 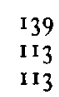 & & $\begin{array}{l}\mathrm{I} .6859 \\
\mathrm{r} .6053 \\
1.4880\end{array}$ & & $\begin{array}{r}.4941 \\
.3730 \\
.2975 \\
\end{array}$ & $\mid \begin{array}{l}78 . \text { I } 8 \\
78.477 \\
78.568\end{array}$ & $\mid \begin{array}{r}71.623 \\
72.193 \\
*_{7} 1.092\end{array}$ & $\begin{array}{l}\text { Ist control } \\
\text { stunted } \\
2 \mathrm{~d} \text { control }\end{array}$ \\
\hline $\begin{array}{l}\text { F..... } \\
F \ldots \ldots \\
\text { F..... }\end{array}$ & $\mid \begin{array}{c}127 \\
127 \\
80-100\end{array}$ & $\begin{array}{r}113.2 \\
70.9 \\
77.2\end{array}$ & $\begin{array}{l}160 \\
132 \\
139\end{array}$ & $\begin{array}{l}135 \\
105 \\
115\end{array}$ & & $\begin{array}{l}1.7698 \\
1.7394 \\
1.5110\end{array}$ & & $\begin{array}{l}.4459 \\
.3404 \\
.3359\end{array}$ & $\begin{array}{l}78.675 \\
78.836 \\
79.139\end{array}$ & $\begin{array}{l}72 \cdot 303 \\
73 \cdot 413 \\
73.86 \mathrm{I}\end{array}$ & $\begin{array}{l}\text { Ist control } \\
\text { stunted } \\
2 \mathrm{~d} \text { control }\end{array}$ \\
\hline \multicolumn{12}{|c|}{ Averages. } \\
\hline $\begin{array}{l}\mathbf{F}+\mathbf{M} \\
\mathbf{F}+\mathbf{M} \\
\mathbf{F}+\mathbf{M}\end{array}$ & $\left|\begin{array}{c}170 \\
170 \\
80-100\end{array}\right|$ & $\begin{array}{r}146.4 \\
91.5 \\
86.3\end{array}$ & $\begin{array}{l}175 \\
144 \\
147\end{array}$ & $\begin{array}{l}143 \\
108 \\
120\end{array}$ & $\begin{array}{l}1: 0.823 \\
1: 0.750 \\
1: 0.816\end{array}$ & $\begin{array}{l}1.7360 \\
1.6267 \\
1.6098\end{array}$ & $\begin{array}{l}1.772 \\
1.646 \\
1.629\end{array}$ & $\begin{array}{l}.4877 \\
.3699 \\
\cdot 3^{604}\end{array}$ & $\begin{array}{l}78.3^{8} 4 \\
78.616 \\
78.889\end{array}$ & $\begin{array}{l}71.280 \\
72.602 \\
72.796\end{array}$ & $\begin{array}{l}\text { Ist control } \\
\text { stunted } \\
2 \mathrm{~d} \text { control }\end{array}$ \\
\hline
\end{tabular}

* This is the only exceptional case, where percentage of water in the second control is less than that of the stunted.

that of the tail is considerably less in the stunted rats than in the control rats. The ratio just mentioned is found to be on the average I : 0.82 in both "first" and "second controls" while

1 The measurement taken from the tip of the nose to the anus is designated as "body length" while that from the anus to the tip of the tail is designated "tail length." 
in the stunted rats the ratio is $I: 0.75$. Underfeeding therefore produces short tailed individuals. The nature of this result has still to be investigated.

Central nervous system.- The weight of the brain and spinal cord and the percentage of water in both were separately determined according to the usual procedure.

The weight of the encephalon was found to be normal to the body weight in both the controls and stunted rats, the brain weight of the first controls is heaviest and that of the "stunted" and "second controls" follow in the order named. The relation between body and brain weights was tested by the formula,

Brain weight $=0.554+0.569 \log$ (body weight -8.7$)$.

This formula has been developed through the study of our laboratory records and gives us the theoretical weight of the brain for any body weight. The former was found to be normal even in the stunted group. As seen from the table, the difference between calculated and observed brain weights on the average was about $\mathbf{I} .5$ per cent, indicating a normal relation of the brain weight to the given body weight. Thus we conclude that the normal relation between the body and brain weights was not disturbed by stunting.

We have as yet no satisfactory method for determining the normal weight of the spinal cord in respect to either body weight or any other characters. Nevertheless the proportional weight of the spinal cord in the experimented and in the second control rats with respect to the brain and body weights suggests that it also has grown normally (see Table I). Therefore we conclude that the weight of the spinal cord and brain are similarly related to the body weight. Consequently so far as the weight of the central nervous system is concerned, the normal relation to the body weight is still maintained by the stunted rats.

It is interesting to note in this connection that the definite relation between the body and brain weights is not disturbed even when the growth of the body has been considerably accelerated by means of the lecithin ${ }^{2}$ or when the rats have been once starved and then returned to normal diet so that the final body weights

\footnotetext{
2 The effect of lecithin on the growth of the white rat. American Fournal of Physiology, vol. 10, no. I. I905.
} 
become normal to the given age. ${ }^{3}$ Whether or not this definite relation between the brain and body weights can still be maintained even when we modify the conditions in other ways will be the subject of further investigations.

Percentage of water in the central nervous system.-The percentage of water in the central nervous system was always higher in the stunted rats than in the first controls, despite the fact that ages of the two groups were the same. On the other hand, this value in the stunted rats-though slightly less-was very close to that of the second controls which were much younger. It has been established in the laboratory that among rats of the same age, those with heavier brains have a smaller percentage of water than those with lighter brains. Therefore the higher percentage of water in the stunted rats as compared with the first controls indicates "a usual" rather than "an unusual" condition, since we should expect to find a somewhat higher percentage of water in the rats with less heavy brain at a given age. We conclude therefore that the percentage of water in the central nervous system in both the controls and stunted rats is normal, in the latter of course having due regard for age and body weight, as well as weights of the brain and spinal cord.

Since the percentage of water and that of the extract are inversely related we may infer that somewhat greater percentage of water found in the central nervous system in the stunted rat indicates with highest probability relatively smaller development of the medullated nerve fibers in that organ when compared with that of the first controls. This statement is correct at least for the peripheral system, as a recent investigation by Mrs. J. W. HAYES shows that the number of medullated fibers in the second spinal nerve in heavier albino rats is greater than that in the less heavy rats of the same age. A further discussion of this general point is however reserved for a future publication.

Conclusions.-Our final conclusions are, then, that aside from the shorter length in the body and tail, which is not only absolute but relative also, the stunted rats differ from the normal rats only in the absolute magnitude of the measured characters, while, on the other hand, when differences in the central nervous system

\footnotetext{
${ }^{3}$ Effect of partial starvation followed by a return to normal diet on the growth of the body and central nervous system of albino rats. American fournal of Physiology, vol. 17, no. 5." 1907 .

* As yet unpublished.
} 
are compared with the growth of the entire body the growth of the stunted rats may be considered just as normal as that of the controls.

The stunted rats were made the subject of tests, by Mr. JoHN W. HAYEs, fellow of psychology in the University of Chicago, to determine whether their behavior was modified by their arrested growth, and the results will be published by him later. 